\title{
Chromogenic detection of nerve agent mimics $\dagger$
}

\author{
Ana M. Costero, ${ }^{* a}$ Salvador Gil, ${ }^{a}$ Margarita Parra, ${ }^{a}$ Pedro M. E. Mancini, ${ }^{a}$ \\ Ramón Martínez-Máñez, ${ }^{* b}$ Félix Sancenón ${ }^{a}$ and Santiago Royo ${ }^{b}$
}

\author{
Received (in Cambridge, UK) 2nd July 2008, Accepted 2nd September 2008 \\ First published as an Advance Article on the web 14th October 2008 \\ DOI: $10.1039 / \mathrm{b811247a}$
}

\section{A new chromogenic protocol for the selective detection of nerve agent mimics is reported.}

The current rise in international concern over criminal terrorist attacks via chemical warfare $(\mathrm{CW})$ agents has resulted in an increasing interest in the detection of these lethal chemicals. Among CW species, nerve agents are extremely dangerous and their high toxicity and ease of production underscore the need to detect these deadly chemicals via quick and reliable procedures. A number of detection systems have been developed, most of them based on enzymatic and physical methodologies. ${ }^{1}$ However, these usually show limitations such as low selectivity, lack of portability and a certain complexity in their use. An alternative to these classical methods that has been gaining interest in recent years is the development of fluorogenic or chromogenic chemosensors or reagents. ${ }^{2}$ Reported paradigms involve PET-based fluorescent probes, ${ }^{3}$ colorimetric probes with oximate-containing derivatives, ${ }^{4}$ molecular imprinting polymers, ${ }^{5}$ nanoparticles, ${ }^{6}$ carbon nanotubes, ${ }^{7}$ porous silicon ${ }^{8}$ or displacement-like assays. ${ }^{9}$ Most of these reported protocols rely on fluorescence changes and as far as we know chromogenic systems for nerve agent detection in aqueous solution or as vapour are rare. Some reported colorimetric examples employ enzymatic methods and are based on the inhibition of the activity of the enzyme acetylcholine esterase. ${ }^{10}$ Despite these interesting examples, colorimetric detection is particularly appealing as it requires low-cost and widely used instrumentation and offers the possibility to detect "with the naked eye" target analytes in rapid semi-quantitative assays. Following our interest in using supramolecular-inspired concepts for the development of chromogenic protocols, we report herein the design of colorimetric probes for nerve agents.

Traditionally the development of colorimetric probes usually relies on the advanced design of two components: (i) a tailor-made binding or reactive site and (ii) a colorimetric event. For the former we selected the suitable properties of 2-(2-(dimethylamino)phenyl)ethanol derivatives (see Scheme 1). This group contains a nucleophile, the hydroxyl moiety, which is known to undergo acylation reactions with phosphonate substrates to form intermediate II that suffers a rapid intramolecular $N$-alkylation to yield III, a quaternary ammonium salt. ${ }^{3}$

\footnotetext{
${ }^{a}$ Departamento de Química Orgánica, Facultad de Ciencias Químicas, Universitat de Valencia, 46100 Burjassot Valencia, Spain.

E-mail: ana.costero@uv.es

${ }^{b}$ Instituto de Química Molecular Aplicada, Departamento de Química, Universidad Politécnica de Valencia, Camino de Vera s/n, 46022

Valencia, Spain.E-mail: rmaez@qim.upv.es

$\dagger$ Electronic supplementary information (ESI) available: ${ }^{1} \mathrm{H}-\mathrm{NMR}$ and ${ }^{13} \mathrm{C}-\mathrm{NMR}$ spectra of receptor 1 and ${ }^{1} \mathrm{H}-\mathrm{NMR}$ spectrum of receptor 2. See DOI: 10.1039/b811247a
}

Remaining with the versatility of the last approach and at the same time being interested in the design of colorimetric probes we envisioned that the coupling of the dimethylaminophenyl donor group with an acceptor moiety (A) could be a suitable approach for the design of tailor-made colorimetric probes for nerve agents' detection. We expected that the conversion of the tertiary amine I to the quaternary ammonium III upon reaction with certain organophosphorus (OP) substrates would dramatically change the electronic donor properties of the nitrogen atom thus resulting in a decrease of the push-pull character of the dye and in a colour modulation.

As a proof-of-the-concept and using 2-(2-(dimethylamino)phenyl)ethanol (DAPE) as a building block we prepared the chromoreactand 1 (see Scheme 2) $\ddagger$ The starting compound DAPE was synthesized from 2-nitrotoluene that was in a first step converted into 2-(2-nitrophenyl)ethanol following a previously described method. ${ }^{11}$ Then, a reductive amination in the presence of formaldehyde gives rise to 2-(2-(dimethylamino)phenyl)ethanol. ${ }^{12}$ The new probe 1 was prepared from the reaction of DAPE with the diazonium salt of 4-nitroaniline using known procedures for the preparation of azo dyes. ${ }^{13}$

As a first step, the reactivity of $\mathbf{1}$ was tested with diethyl chlorophosphate (DCP), diisopropyl fluorophosphate (DFP) and diethyl cyanophosphate (DCNP) in acetonitrile. These organophosphates have been widely used as simulants as they display a reactivity similar to that of nerve agents such as Tabun, Sarin and Soman, yet they lack their toxicity. Acetonitrile solutions of chromoreactand $\mathbf{1}$ display an absorption spectrum typical of azo dyes with an intense absorption band $(\log \varepsilon>4)$ at $410 \mathrm{~nm}$. This yellow band has a charge-transfer character due to the presence of an electron donor anilinium group and a nitrophenyl moiety acting as electron acceptor. Upon addition of 100 equiv. of DCP to acetonitrile solutions of chromoreactand 1 a hypsochromic shift of $85 \mathrm{~nm}$ (Fig. 1) was observed that resulted in a modulation from yellow to colourless. This shift to shorter wavelengths is consistent with the intramolecular cyclization process; i.e. the $N, N$-dimethylanilino moiety drastically reduces its donor character

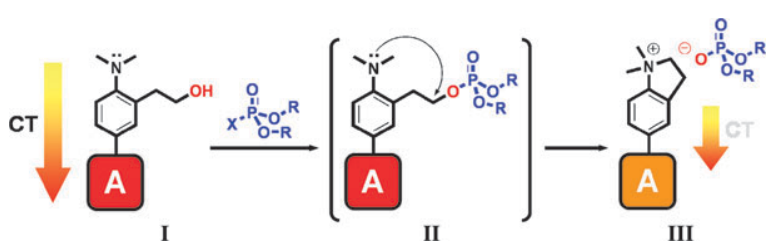

Scheme 1 Colorimetric sensing protocol. A 2-(2-(dimethylamino)phenyl)ethanol (DAPE) group acts as donor in charge-transfer dyes such as I containing an acceptor group (A). In III there is a drastic reduction of the donor ability of the amine group resulting in a remarkable weakening of the charge-transfer (CT) band. 


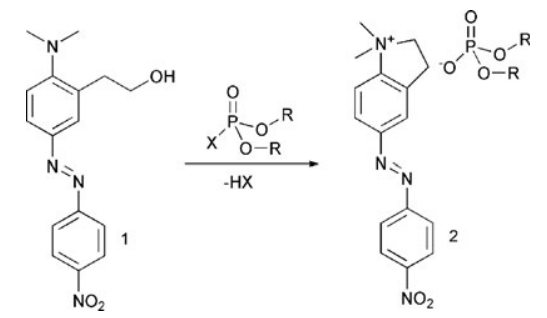

Scheme 2 Transformation of the azo dye 1 to the corresponding ammonium derivative via acylation with a phosphate substrate and further intramolecular cyclization.

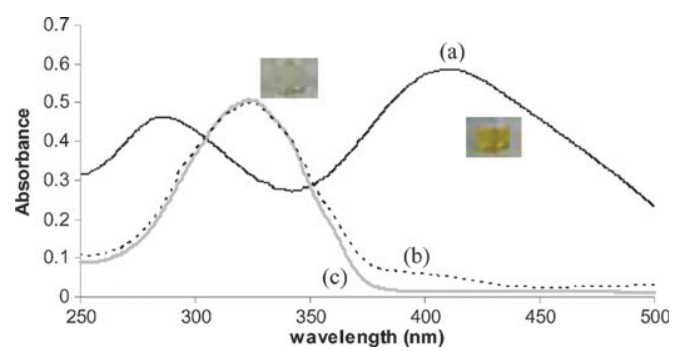

Fig. 1 Normalized absorption spectra of: (a) chromoreactand 1 (acetonitrile, $1.0 \times 10^{-5} \mathrm{~mol} \mathrm{dm}^{-3}$ ), (b) 1 with 100 equiv. of DCP and (c) the cyclization product obtained on reaction of $\mathbf{1}$ with $p$-toluenesulfonyl chloride (see text). The inset photographs show the colour of probe 1 and the bleaching observed upon addition of DCP.

(vide ante). A similar behaviour was observed in the presence of DFP and DCNP. For instance, a detection limit of $1.0 \times 10^{-4} \mathrm{~mol} \mathrm{dm}^{-3}$ for DCNP and DCP was found.

Additionally, in order to assess the mechanism involved in the observed chromogenic response, compound $\mathbf{2}$ was also prepared following a different synthetic route involving the reaction of chromoreactand $\mathbf{1}$ with $p$-toluenesulfonyl chloride in the presence of sodium carbonate in acetonitrile. This gives the corresponding tosylated derivative that suffered a spontaneous cyclization to give $\mathbf{2}$. The formation of $\mathbf{2}$ is easily detected in the ${ }^{1} \mathrm{H}-\mathrm{NMR}$ spectra of the final product that shows one triplet centered at $4.36 \mathrm{ppm}$ indicative of a methylene subunit located near the quaternary ammonium. Also, a significant long-range ${ }^{1} \mathrm{H}_{-}{ }^{13} \mathrm{C}$ coupling between this signal and those ${ }^{13} \mathrm{C}$ signals corresponding to the methyls (54 ppm) and to the aromatic carbon (149 ppm) attached to the $N, N$-dimethylanilinium fragment points toward the unambiguous formation of the cyclized product. It was unambiguously confirmed that the product obtained by tosylation was the same as that obtained from the reaction of 1 with the DCP simulant (see Fig. 1 for the UV spectrum), indicating that the reaction in Scheme 1 is responsible for the colour modulation.

In a further step, the reactivity of $\mathbf{1}$ with the organophosphorus (OP) compounds shown in Fig. 2 was studied in mixed water-acetonitrile $75: 25 \mathrm{v} / \mathrm{v}$ mixtures buffered at $\mathrm{pH} 7$ (MES $5.0 \times 10^{-2} \mathrm{~mol} \mathrm{dm}^{-3}$ ). As stated above, a selective bleaching was found in the presence of DCP, DFP and DCNP, whereas solutions stay orange-yellow for the remaining OP species (no reaction was observed even after a long time). In order to achieve a better understanding of the reaction, the reactivity between 1 and DCP, DCNP or DFP in acetonitrile under

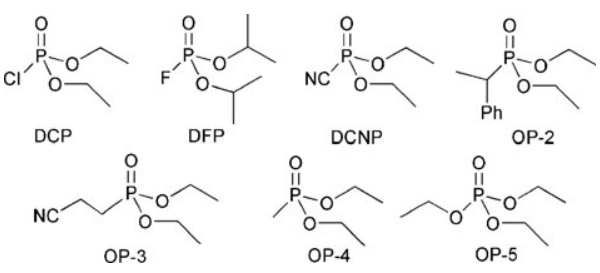

Fig. 2 Chemical structures of the warfare agent simulants.

pseudo first-order kinetic conditions with an excess of the corresponding simulant was studied. As has been suggested for similar systems, the reaction of the alcohol with the phosphate derivatives to form the phosphate ester intermediate is slow relative to the intramolecular cyclization. ${ }^{3}$ Monitoring the absorbance intensity at $410 \mathrm{~nm}$ and plotting $\ln \left[\left(A_{0}-A\right) / A\right]$ versus time (where $A_{0}$ is the final absorbance and $A$ is the absorbance at a given time) allowed the determination of the rate constants $(k)$ with values of $0.13 \mathrm{~s}^{-1}, 0.061 \mathrm{~s}^{-1}$ and $0.20 \mathrm{~s}^{-1}$ for DCP, DCNP and DFP, respectively. Therefore the half-life was calculated $\left(t_{1 / 2}=\ln 2 / k\right)$ to be approximately $5.3 \mathrm{~s}, 11.4 \mathrm{~s}$ and $3.5 \mathrm{~s}$ for DCP, DCNP and DFP, respectively. Fig. 3 shows the absorbance decrease of the visible band of dye 1 on reaction with DCP.

Motivated by these favourable features we took a step forward towards the potential use of $\mathbf{1}$ for in situ sensing and rapid screening applications. For this purpose the molecular probe 1 was adsorbed on silica gel. First, a solution of $\mathbf{1}$ $\left(1 \times 10^{-5} \mathrm{~mol} \mathrm{dm}^{-3}\right)$ and $\operatorname{MES}\left(5 \times 10^{-2} \mathrm{~mol} \mathrm{dm}^{-3}\right)$ in acetonitrile-water $(1: 3)$ was prepared. Then, $2 \mathrm{~mL}$ of this solution were adsorbed on silica gel $(500 \mathrm{mg})$ and air-dried, finally resulting in a light orange solid. In a first test, the coloured support containing 1 was placed in a $1000 \mathrm{~mL}$ flask that contained $c a .5$ ppm of DCP vapour (obtained by evaporation of a solution of the simulant into the flask volume). A clear change from orange-yellow to colourless was observed for the sensor-loaded silica gel.

In a second test, the orange-yellow coloured silica was placed on a column and a water-acetonitrile $75: 25 \mathrm{v} / \mathrm{v}$ solution containing DCP buffered at $\mathrm{pH} 7\left(C_{\mathrm{DCP}}=1.0 \times 10^{-3} \mathrm{~mol} \mathrm{dm}^{-3}\right.$, MES $5.0 \times 10^{-2} \mathrm{~mol} \mathrm{dm}^{-3}$ ) was passed through. As the silica comes into contact with the sample solution it becomes colourless (see Fig. 4). In both tests the response time was a few seconds. The bleaching of the coloured silica support containing $\mathbf{1}$ in the presence of vapours or mixed aqueous solutions of DCP is consistent with the reaction shown in Scheme 2.

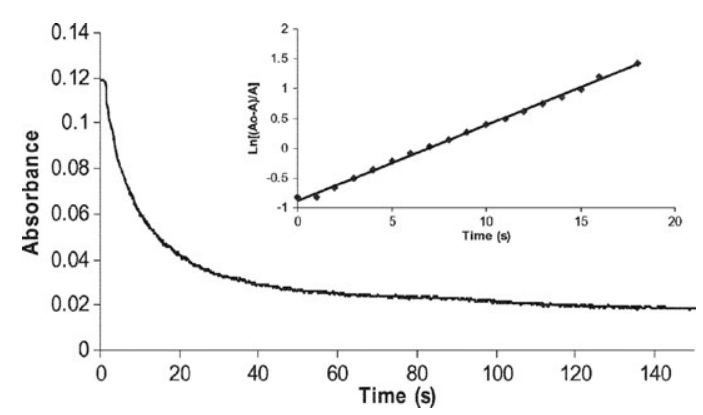

Fig. 3 Absorption changes at $410 \mathrm{~nm}$ upon reaction of 1 with DCP. Inset: first-order kinetic plot. 


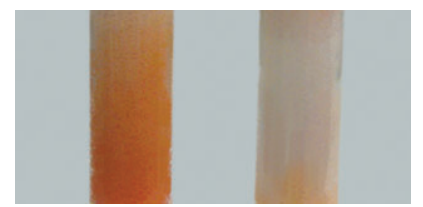

Fig. 4 Left: a glass tube containing silica gel with dispersed 1. Right: silica gel containing $\mathbf{1}$ after the addition of water-acetonitrile $75: 25 \mathrm{v} / \mathrm{v}$ mixtures containing DCP buffered at $\mathrm{pH} 7\left(C_{\mathrm{DCP}}=1.0 \times\right.$ $10^{-3} \mathrm{~mol} \mathrm{dm}^{-3}$, MES $5.0 \times 10^{-2} \mathrm{~mol} \mathrm{dm}^{-3}$ ).

In summary, a new chromoreactand for the colorimetric sensing of nerve agent simulants has been prepared. This chromoreactand displays an intramolecular cyclization reaction coupled with a colour change upon interaction with certain nerve agent simulants. The facts that the probe retains its signalling abilities upon adsorption on silica and displays colour modulations to nerve agent simulants as both vapours or in mixed aqueous solution make this method a suitable alternative to other systems used in the detection of toxic nerve agents. It is noteworthy that the chemosensor $\mathbf{1}$ reacts only with DCP, DFP and DCNP that show close chemical structures to Sarin, Soman and Tabun, whereas 1 remains silent in the presence of other organophosphorus derivatives such as OP-2-5. Additionally, the approach is highly modular in concept bearing in mind that a number of acceptor groups can be anchored to the 2-(2-(dimethylamino)phenyl)ethanol donor moiety (see Scheme 1) pointing towards the potential preparation of a range of colorimetric probes for the detection of nerve agents based on push-pull chromophores.

\section{Notes and references}

$\ddagger$ Synthesis of 2-(2-N,N-dimethylaminophenyl)ethanol: 2-nitrotoluene $(9.2 \mathrm{~g}, 67.2 \mathrm{mmol})$, sodium phenoxide $(0.06 \mathrm{~g}, 0.56 \mathrm{mmol})$ and paraformaldehyde $(95 \%)(0.9 \mathrm{~g}, 25 \mathrm{mmol})$ in DMSO $(20 \mathrm{~mL})$ were heated under stirring at $60-70{ }^{\circ} \mathrm{C}$ for $1 \mathrm{~h}$. The cold reaction mixture was poured into water $(20 \mathrm{~mL})$ and extracted with ethyl ether. The combined organic phases were washed (aq. $\mathrm{NaCl})$, dried $\left(\mathrm{MgSO}_{4}\right)$, evaporated and the residue was distilled (Kugelrohr, $160{ }^{\circ} \mathrm{C}$, $0.2 \mathrm{mmHg}$ ) to yield 2-(2-nitrophenyl)ethanol (4.3 g, 37\%). Spectral data were in agreement with those described in the literature. ${ }^{8}$ Then, 2-(2-nitrophenyl)ethanol (3.30 g, $19.7 \mathrm{mmol})$, formaldehyde $(37 \%)$ $(4.83 \mathrm{~mL}, 32.3 \mathrm{mmol})$, abs. ethanol $(200 \mathrm{ml})$ and $\mathrm{Pd} / \mathrm{C}(10 \%)(480 \mathrm{mg})$ were placed under an $\mathrm{H}_{2}$ atmosphere until the uptake of hydrogen ceased. After filtration through Celite the solvent was evaporated and the residue was dissolved in chloroform and extracted with aq. $\mathrm{HCl}$ $(1 \mathrm{M}, 2 \times 50 \mathrm{~mL})$. The aqueous phase was basified with sat. $\mathrm{Na}_{2} \mathrm{CO}_{3}$ and extracted with chloroform. After drying $\left(\mathrm{MgSO}_{4}\right)$ the solvent was evaporated to give 2-(2- $N, N$-dimethylaminophenyl)ethanol $(2.85 \mathrm{~g}$, $84 \%)$ as a light yellow oil.

${ }^{1} \mathrm{H}$ NMR $\left(\mathrm{CDCl}_{3}, 400 \mathrm{MHz}\right) \delta 7.3-7.0(\mathrm{~m}, 4 \mathrm{H}), 5.3$ (br. s, $\left.1 \mathrm{H}\right), 3.85$ (t, $J=11.6 \mathrm{~Hz}, 2 \mathrm{H}), 3.01$ (t, $J=11.6 \mathrm{~Hz}, 2 \mathrm{H}), 2.70(\mathrm{~s}, 6 \mathrm{H}) \mathrm{ppm}$; ${ }^{13} \mathrm{C}\left\{{ }^{1} \mathrm{H}\right\} \mathrm{NMR}\left(\mathrm{CDCl}_{3}, 100 \mathrm{MHz}\right): \delta 152.1,136.0,131.1,127.6,124.9$, 120.0, 64.2, 44.9, $36.0 \mathrm{ppm}$; IR (neat) 3367, 3059, 3020, 2937, 2360, 2826, 2785, 1597, 1492, 1451, 1046, 945, 768 and $749 \mathrm{~cm}^{-1}$. HRMS-EI $m / z 165.1153\left[\mathrm{M}^{+}\right.$; calcd for $\left.\mathrm{C}_{10} \mathrm{H}_{15} \mathrm{NO}: 165.1154\right]$.

Synthesis of 1: 4-Nitroaniline $(0.836 \mathrm{~g}, 6.05 \mathrm{mmol})$, conc. sulfuric acid $(1.25 \mathrm{~mL}, 23 \mathrm{mmol})$ and water $(8 \mathrm{~mL})$ were stirred and slightly heated until the 4-nitroaniline was completely dissolved and then the mixture was placed in an ice-bath $\left(0-5^{\circ} \mathrm{C}\right)$ for 10 min before a $\mathrm{NaNO}_{2}(0.418 \mathrm{~g}$, $6.05 \mathrm{mmol})$ solution in water $(4 \mathrm{~mL})$ was added dropwise. After stirring for an additional $10 \mathrm{~min}$ at $0-5{ }^{\circ} \mathrm{C}$, a solution of the amine synthesised above $(1.0 \mathrm{~g}, 6.05 \mathrm{mmol})$, conc. $\mathrm{HCl}(1.3 \mathrm{~mL}, 15.1 \mathrm{mmol})$ and water $(4 \mathrm{~mL})$ was added dropwise during $15 \mathrm{~min}$. The resulting orange solution was stirred for $15 \mathrm{~min}$ in an ice-bath and $15 \mathrm{~min}$ at room temperature, then it was neutralized with $\mathrm{Na}_{2} \mathrm{CO}_{3}$ and extracted with $\mathrm{CH}_{2} \mathrm{Cl}_{2}$. The dried $\left(\mathrm{MgSO}_{4}\right)$ organic phases were evaporated to give a dark oil that was dissolved in ethyl acetate. Upon addition of hexane, a dark red precipitate appeared, identified as $\mathbf{1}(1.2 \mathrm{~g}, 63 \%)$, mp 98-100 ${ }^{\circ} \mathrm{C} .{ }^{1} \mathrm{H}$ NMR $\left(\mathrm{CDCl}_{3}, 400 \mathrm{MHz}\right) \delta 8.36(\mathrm{~d}, J=9.0 \mathrm{~Hz}$, $2 \mathrm{H}), 7.98(\mathrm{~d}, J=9.0 \mathrm{~Hz}, 2 \mathrm{H}), 7.85(\mathrm{~d}, J=8.1 \mathrm{~Hz}, 1 \mathrm{H}), 7.81(\mathrm{~s}, 1 \mathrm{H})$, $7.26(\mathrm{~d}, J=8.1 \mathrm{~Hz}, 1 \mathrm{H}), 3.95(\mathrm{t}, J=5.8 \mathrm{~Hz}, 2 \mathrm{H}), 3.10(\mathrm{t}, J=5.8 \mathrm{~Hz}$, $2 \mathrm{H}), 2.83$ (s, 6H) ppm; ${ }^{13} \mathrm{C}\left\{{ }^{1} \mathrm{H}\right\}$ NMR $\left(\mathrm{CDCl}_{3}, 100 \mathrm{MHz}\right): \delta 156.7$, 155.9, 148.8, 148.4, 135.4, 125.4, 124.7, 123.9, 123.2, 119.9, 63.8, 44.6, $35.8 \mathrm{ppm}$; IR (neat) 2948, 2873, 1591, 1517, 1345, 1099, 1039, 858 and $827 \mathrm{~cm}^{-1}$. HRMS-EI $\mathrm{m} / \mathrm{z} 314.1371\left[\mathrm{M}^{+}\right.$; calcd. for $\mathrm{C}_{16} \mathrm{H}_{18} \mathrm{~N}_{4} \mathrm{O}_{3}$ : 314.1379].

Synthesis of 2: To a stirred mixture of $1(63 \mathrm{mg}, 0.2 \mathrm{mmol})$ and $\mathrm{K}_{2} \mathrm{CO}_{3}$ $(56 \mathrm{mg}, 0.4 \mathrm{mmol})$ in acetonitrile $(1 \mathrm{~mL})$, tosyl chloride $(36 \mathrm{mg}$, $0.2 \mathrm{mmol})$ in acetonitrile $(0.5 \mathrm{~mL})$ was slowly added. After stirring at room temperature for $6 \mathrm{~h}$, toluene $(5 \mathrm{~mL})$ was added. The formed precipitate was filtered to give 2 (as its tosylate salt) $(46 \mathrm{mg}, 0.1 \mathrm{mmol}$ ) as a white solid, $\mathrm{mp}>350{ }^{\circ} \mathrm{C} .{ }^{1} \mathrm{H}$ NMR $\left(\mathrm{CD}_{3} \mathrm{OD}, 400 \mathrm{MHz}\right) \delta 8.46$ $(\mathrm{d}, J=8.8 \mathrm{~Hz}, 2 \mathrm{H}), 8.15(\mathrm{~m}, 4 \mathrm{H}), 8.02(\mathrm{~d}, J=8.7 \mathrm{~Hz}, 1 \mathrm{H}), 7.72(\mathrm{~d}$, $J=7.8 \mathrm{~Hz}, 2 \mathrm{H}), 7.25(\mathrm{~d}, J=7.8 \mathrm{~Hz}, 2 \mathrm{H}), 4.36(\mathrm{t}, J=7.2 \mathrm{~Hz}, 2 \mathrm{H})$, $3.65(\mathrm{~s}, 6 \mathrm{H}), 3.59(\mathrm{t}, J=7.2 \mathrm{~Hz}, 2 \mathrm{H}) \mathrm{ppm} ;{ }^{13} \mathrm{C}\left\{{ }^{1} \mathrm{H}\right\} \mathrm{NMR}\left(\mathrm{CDCl}_{3}\right.$, $100 \mathrm{MHz}): \delta 155.2,153.8,149.0,142.1,140.4,128.4,125.6,124.9$, 124.6, 123.6, 120.3 118.2, 68.5, 54.0, 26.6, 19.9 ppm; IR (neat) 3082 , 2961, 1628, 1398, 1381, 1127, 1007, 831, 701, and $664 \mathrm{~cm}^{-1}$. HRMS-EI $m / z 297.1355$ [M ${ }^{+}$; calcd. for $\left.\mathrm{C}_{16} \mathrm{H}_{17} \mathrm{~N}_{4} \mathrm{O}_{2}: 297.1352\right]$.

1 L. M. Eubanks, T. J. Dickerson and K. D. Janda, Chem. Soc. Rev., 2007, 36, 458; H. H. Hill, Jr and S. J. Martin, Pure Appl. Chem., 2002, 74, 2281; J. J. Gooding, Anal. Chim. Acta, 2006, 559, 137; K. Brown, Science, 2004, 305, 1228; M. T. McBride, S. Gammon, M. Pitesky, T. W. O'Brien, T. Smith, J. Aldrich, R. G. Langlois, B. Colston and K. S. Venkateswaran, Anal. Chem., 2003, 75, 1924.

2 S. Royo, R. Martínez-Máñez, F. Sancenón, A. M. Costero, M. Parra and S. Gil, Chem. Commun., 2007, 4839; B. C. Giordano and G. E. Collins, Curr. Org. Chem., 2007, 11, 255; M. Burnworth, S. J. Rowan and C. Werder, Chem.-Eur. J., 2007, 13, 7828.

3 K. A. Van Houten, D. C. Heath and R. S. Pilato, J. Am. Chem. Soc., 1998, 120, 12359; S.-W. Zhang and T. M. Swager, J. Am. Chem. Soc., 2003, 125, 3420; T. J. Dale and J. Rebek, Jr, J. Am. Chem. Soc., 2006, 128, 4500; F. Ilhan, D. S. Tyson and M. A. Meador, Chem. Mater., 2004, 16, 2978; S. Bencic-Nagale, T. Sternfeld and D. R. Walt, J. Am. Chem. Soc., 2006, 128, 5041.

4 K. J. Wallace, J. Morey, V. M. Lynch and E. V. Anslyn, New J. Chem., 2005, 29, 1469; K. J. Wallace, R. I. Fagbemi, F. J. FolmerAndersen, J. Morey, V. M. Lynch and E. V. Anslyn, Chem. Commun., 2006, 3886; F. Terrier, P. Rodríguez-Dafonte, E. Le Guével and G. Moutiers, Org. Biomol. Chem., 2006, 4, 4352; H. S. Hewage, K. J. Wallace and E. V. Anslyn, Chem. Commun., 2007, 3909.

5 A. L. Jenkins, O. M. Uy and G. M. Murray, Anal. Commun., 1997, 34, 221; A. L. Jenkins, O. M. Uy and G. M. Murray, Anal. Chem., 1999, 71, 373; A. L. Jenkins and S. Y. Bae, Anal. Chim. Acta, 2005, 542, 32; G. E. Southard, K. A. Van Houten, E. W. Ott, Jr and G. M. Murray, Anal. Chim. Acta, 2007, 581, 202; R. Shunmugam and G. N. Tew, Chem.-Eur. J., 2008, 14, 5409.

6 V. Pavlov, Y. Xiao and I. Willner, Nano Lett., 2005, 5, 649; L. Wang, K. D. Cole, A. K. Gaigalas and Y.-Z. Zhang, Bioconjugate Chem., 2005, 16, 194.

7 F. Wang, H. Gu and T. M. Swager, J. Am. Chem. Soc., 2008, 130, 5392.

8 H. Sohn, S. Létant, M. J. Sailor and W. C. Troger, J. Am. Chem. Soc., 2000, 122, 5399; S. Létant, B. R. Hart, S. R. Kane, M. Z. Hadi, S. J. Shields, T.-C. Cheng, V. K. Rastogi, J. Del Eckels and J. G. Reynolds, Mater. Res. Soc. Symp. Proc., 2005, 828, A1.8.1.

9 D. Knapton, M. Burnworth, S. J. Rowan and C. Weder, Angew. Chem., Int. Ed., 2006, 45, 5825.

10 See for example: W. Trettnak, F. Reininger, E. Zinterl and O. S. Wolfbeis, Sens. Actuators, B, 1993, 11, 87.

11 P. L. Minin and J. C. Walton, J. Org. Chem., 2003, 68, 2960.

12 I. O. Kady and B. Tan, Tetrahedron Lett., 1995, 36, 4031.

13 T. Gunnlaugsson, J. P. Leonard and N. S. Murray, Org. Lett., 2004, 6, 1557; B. C. McKusick, R. E. Heckert, T. L. Cairns, D. D. Coffman and H. F. Mower, J. Am. Chem. Soc., 1958, 80, 2806. 